\title{
Peertechz
}

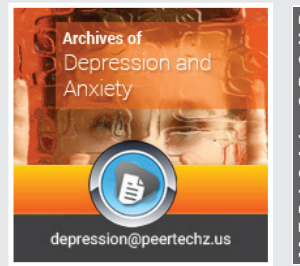

\section{COVID-19: One pandemic shading another}

\section{Camille P Figueiredo* and Felipe M Santana}

Rheumatology Clinic, Dr. Castor Jordão Cobra, São Paulo, SP, Brazil

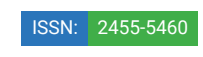

DC

Received: 12 April, 2021

Accepted: 20 April, 2021

Published: 22 April, 2021

*Corresponding author: Camille P Figueiredo, Rheumatology Clinic, Dr. Castor Jordão Cobra, Rua Bento de Andrade 351, São Paulo-SP, 04503-010, Brazil, Tel: +551147803759;

E-mail: figueiredocamille@gmail.com

https://www.peertechzpublications.com

Check for updates
Since March 2020, after the World Health Organization (WHO) officially declared COVID-19 a pandemic, people worldwide has struggled with what can likely be considered the most severe global health crisis of recent times, comprising of $131,000,000$ confirmed cases and more than 2,800,000 deaths [1]. The first registered case was reported in Wuhan, China, in November, $2019[2,3]$ and it took less than three months for the infection to strike Brazil, as the first official COVID-19 Brazilian case was confirmed, in February $25^{\text {th }} 2020$ [4]. As in many unexpected critical health issues, COVID-19 has not only directly affected those infected by it. It also reached those who remained free of disease, however greatly impacted by the socioeconomic consequences of the pandemic. One of these consequences concerns to mental health diseases which has been greatly struck by the pandemic outbreak and has been an issue for COVID-19 survivors, their contacts and those who have not yet had contact with the disease [5]. The prevalence of mental health diseases such as anxiety, depression, acute distress disorder and burnout have since then steeply increased and now it represents by itself an additional pandemic $[6,7]$. Interpersonal contact has greatly been compromised due to the disruption of normal lifestyles and this has been suggested to be a major risk factor for the deterioration of mental health $[8,9]$. Moreover, evidence has emerged of some strong predictors for the development of mental health disorders during COVID-19 pandemic. For instance, women seem to be at a higher risk than men [7,10-13]. Since the outbreak of COVID-19 and its inevitable impacts on daily routine such as cities lockdowns and home quarantines, families have been forced to a more intense indoor interaction. This environment has promoted a fertile ground for an old, well-known and ominous breach in human rights - domestic violence against women - which has since then forced the United Nations (UN) to issue a warning on the matter.

There's increasing evidence that male sex is a risk factor for poor outcomes in COVID-19 infection as compared to female sex. This difference relates both to the susceptibility for contracting
COVID-19 infection as well as for the severity of its clinical course. Differences in immune mechanisms, social vulnerability and even confounding factors, such as smoking habit, may all play a role. No definite explanations for such differences, however, have so far been confirmed [14-16]. For instance, men infected by SARS-CoV-2 face a higher mortality risk than women as reported from China $(2.8 \%$ vs $1.7 \%, \mathrm{n}=44000)[17,18]$. It's also hypothesized that men are more frequently infected with COVID-19 than women due to differences in following appropriate personal preventive measures, such as wearing a mask and avoiding social gathering. Although both men and women are equally exposed to information and guidelines on such measures, women might be more prone to fully comply with them $[19,20]$. A study performed in Spain reported that women scored higher on perceived vulnerability than men [21], hence, exposing themselves less to transmission risks and more frequently following COVID-19 preventive protocols $[22,23]$. This common behavior after a disease threat may be ingrained in mental processes common to women, such as those described by the field of developmental psychology [24].

Actually, being women is currently recognized as a strong predictor for developing anxiety, fear and stress during the ongoing COVID-19 pandemic [25]. For instance, anxiety levels have been shown to be three times higher among women than among men [26]. However great are the direct and indirect impacts of COVID-19 on women's mental health, there's an even more urgent matter that seems to be mentally and physically threatening women's welfare during the pandemic: the rise of domestic violence worldwide [27]. And this is no different in Brazil [28]. The ramping up of lockdown measures exposed the underlying vulnerabilities of women, who are forced to stay at home, work from home and implement social distance while remaining at the same time at close contact with their aggressor [29]. All indirect effects of COVID-19 disturb women happiness, building up distress, depression, anxiety and leading at the very end to impairment in mental health. 
Data summarize the alarming scenario we are just living in: as the pandemic intensifies, reports of domestic violence against women are rapidly spreading worldwide and their partners are taking advantage of physical distancing measures to isolate victims from the appropriate assistance resources [30,31]. In China, the cases of domestic violence were three times greater in February 2020 compared to February 2019 [32]. In Russia, the number of calls to domestic abuse hotlines increased from 6,000 in March 2020 to more than 13,000 in April 2020 [33]. Some authors have also shown a similar increase in developed countries as USA, United Kingdom, Canada and Australia [3437]. It still happens, however, far more often in developing countries [38].

Although these data are concerning, they are not unexpected. It is well-known that $30 \%$ of women experience physical or sexual violence by an intimate partner in their lifetime [39]. During catastrophic situations involving humanitarian crisis, such as war scenarios, natural calamities and the ongoing COVID-19 pandemic, the prevalence of domestic violence tends to escalate $[40]$.

Approaches towards ending domestic violence should ideally consist of a mutual collaboration between governmental and non-governmental organizations, aiming first at those women most vulnerable. These should be integrated in order to prevent the problem, whilst providing shelter, psychological support and education to women, particularly in cases where children are involved. Furthermore, fighting domestic violence consists of continually solving domestic problems, not only during the pandemic but thereafter. As mentioned above, this is not a new issue. All efforts must be carefully implemented, weighting aforementioned bad experiences we have previously learned from other humanitarian crisis. In fact, we must bear in mind we are currently facing two distinct pandemic situations and a collective effort is required to stop both.

\section{References}

1. WHO (2021) WHO Coronavirus (COVID-19) Dashboard. World Health Organization. Link: https://bit.ly/3gutOir

2. Du Z, Wang L, Cauchemez S, Xu X, Wang X, et al. (2020) Risk for Transportation of Coronavirus Disease from Wuhan to Other Cities in China. Emerg Infect Dis 26: 1049-1052. Link: https://bit.ly/3eldpPj

3. Wu F, Zhao S, Yu B, Chen YM, Wang W, et al. (2020) A new coronavirus associated with human respiratory disease in China. Nature 579: 265-269. Link: https://bit.ly/32CYOJK

4. Rodriguez-Morales AJ, Gallego V, Escalera-Antezana JP, Mendez CA, et al (2020) COVID-19 in Latin America: The implications of the first confirmed case in Brazil. Travel Med Infect Dis 35: 101613. Link: https://bit.ly/3avYtwK

5. Amsalem D, Dixon LB, Neria Y (2021) The Coronavirus Disease 2019 (COVID-19) Outbreak and Mental Health: Current Risks and Recommended Actions. JAMA Psychiatry 78: 9-10. Link: https://bit.ly/3gCobmW

6. Ammar A, Mueller P, Trabelsi K, Chtourou H, Boukhris O, et al. (2020) Psychological consequences of COVID-19 home confinement: The ECLB-COVID19 multicenter study. PLoS One 15: e0240204. Link: https://bit.ly/3enwJvp

7. Ricci-Cabello I, Meneses-Echavez JF, Serrano-Ripoll MJ, Fraile-Navarro D, de Roque MAF, et al. (2020) Impact of viral epidemic outbreaks on mental health of healthcare workers: a rapid systematic review and meta-analysis. J Affect Disord 277: 347-357. Link: https://bit.ly/3nlCYEh

8. Gammon J, Hunt $\mathrm{J}$ (2018) Source isolation and patient wellbeing in healthcare settings. Br J Nurs 27: 88-91. Link: https://bit.ly/3tIAX79

9. WHO (2020) Mental health and psychosocial considerations during the COVID-19 outbreak World Health Organization. Link: https://bit.ly/3v96HCJ

10. Garcia-Fernandez L, Romero-Ferreiro V, Lopez-Roldan PD, Padilla S, CaleroSierra I, et al. (2020) Mental health impact of COVID-19 pandemic on Spanish healthcare workers. Psychol Med 1-3. Link: https://bit.ly/3dCSdVZ

11. Xiao X, Zhu X, Fu S, Hu Y, Li X, et al. (2020) Psychological impact of healthcare workers in China during COVID-19 pneumonia epidemic: A multi-center cross-sectional survey investigation. J Affect Disord 274: 405-410. Link: https://bit.ly/32zCCQE

12. Yang L, Yin J, Wang D, Rahman A, Li X (2020) Urgent need to develop evidencebased self-help interventions for mental health of healthcare workers in COVID-19 pandemic. Psychol Med 1-2. Link: https://bit.ly/3gAZly」

13. Zhang WR, Wang K, Yin L, Zhao WF, Xue Q, et al. (2020) Mental Health and Psychosocial Problems of Medical Health Workers during the COVID-19 Epidemic in China. Psychother Psychosom 89: 242-250. Link: https://bit.ly/2QKnkWz

14. Chen N, Zhou M, Dong X, Qu J, Gong F, et al. (2020) Epidemiological and clinical characteristics of 99 cases of 2019 novel coronavirus pneumonia in Wuhan China: a descriptive study. Lancet 395: 507-513. Link: https://bit.ly/3xoBMEL

15. Epidemiology Working Group for Ncip Epidemic Response, C. C. f. D. C., \& Prevention (2020) The epidemiological characteristics of an outbreak of 2019 novel coronavirus diseases (COVID-19) in China. Zhonghua Liu Xing Bing Xue Za Zhi 41: 145-151. Link: https://bit.ly/32CHjJG

16. Liu S, Zhang M, Yang L, Li Y, Wang L, Huang Z, et al. (2017) Prevalence and patterns of tobacco smoking among Chinese adult men and women: findings of the 2010 national smoking survey. J Epidemiol Community Health 71: 154161. Link: https://bit.ly/3gwDhdQ

17. Huang C, Wang Y, Li X, Ren L, Zhao J, Hu Y, et al. (2020) Clinical features of patients infected with 2019 novel coronavirus in Wuhan, China. Lancet 395 497-506. Link: https://bit.ly/3sInnQ1

18. Jiang F, Deng L, Zhang L, Cai Y, Cheung CW, et al. (2020) Review of the Clinical Characteristics of Coronavirus Disease 2019 (COVID-19). J Gen Intern Med 35: 1545-1549. Link: https://bit.ly/3xdOvdd

19. Lau JT, Yang X, Tsui HY, Pang E (2004) SARS related preventive and risk behaviours practised by Hong Kong-mainland China cross border travellers during the outbreak of the SARS epidemic in Hong Kong. J Epidemio Community Health 58: 988-996. Link: https://bit.ly/3x9HHOd

20. Levkovich I, Shinan-Altman S (2021) The impact of gender on emotional reactions, perceived susceptibility and perceived knowledge about COVID-19 among the Israeli public. Int Health Link: https://bit.ly/2P9RqCm

21. Diaz A, Belena A, Zueco J (2020)The Role of Age and Gender in Perceived Vulnerability to Infectious Diseases. Int J Environ Res Public Health 17. Link: https://bit.ly/3avMkHY

22. Haq W, Raza SH, Mahmood T (2020) The pandemic paradox: domestic violence and happiness of women. Peer J 8: e10472. Link: https://bit.ly/3n8vynH

23. Levkovich I, Shinan-Altman S (2020) Impact of the COVID-19 pandemic on stress and emotional reactions in Israel: a mixed-methods study. Int Health Link: Link: https://bit.ly/3xi5PO

24. Hill SE, Prokosch ML, DelPriore DJ (2015) The impact of perceived disease threat on women's desire for novel dating and sexual partners: is variety the best medicine? J Pers Soc Psychol 109: 244-261. Link: https://bit.ly/3eqEAbF 
25. Liu N, Zhang F, Wei C, Jia Y, Shang Z, et al. (2020) Prevalence and predictors of PTSS during COVID-19 outbreak in China hardest-hit areas: Gender differences matter. Psychiatry Res 287: 112921. Link: https://bit.ly/3vbpOHu

26. Kaljee L, Zhang L, Langhaug L, Munjile K, Tembo S, et al. (2017) A randomizedcontrol trial for the teachers' diploma programme on psychosocial care, support and protection in Zambian government primary schools. Psychol Health Med 22: 381-392. Link: https://bit.ly/3tHmSqM

27. Peterman A, Potts A, O'Donnell M, Thompson K, Shah N, et al. (2020) Pandemics and violence against women and children. Link: https://bit.ly/2QNyzgQ

28. Vieira PR, Garcia LP, Maciel ELN (2020) The increase in domestic violence during the social isolation: what does it reveals?. Rev Bras Epidemiol 23 e200033. Link: https://bit.ly/3new5Er

29. Haq SU, Shahbaz P, Boz I (2020) Knowledge, behavior and precautionary measures related to COVID-19 pandemic among the general public of Punjab province, Pakistan. J Infect Dev Ctries 14: 823-835. Link: https://bit.ly/32ESVvs

30. Graham-Harrison E, Giuffrida A, Smith H, Ford L (2020) Lockdowns around the world bring rise in domestic violence.

31. Gupta A, Stahl A (2020) For abused women, a pandemic lockdown holds dangers of its own.

32. Allen-Ebrahimian B (2020) China's domestic violence epidemic. Link: https://bit.ly/3sGEDFo
33. Litvinova D (2020) Russia: Domestic violence reports spike amid virus lockdown. Link: https://bit.ly/3vd66Q0

34. Ivandic R, Kirchmaier T, Linton B (2020) Changing Patterns of Domestic Abuse during COVID-19 Lockdown. Link: https://bit.ly/3tGMLGZ

35. Kovler ML, Ziegfeld S, Ryan LM, Goldstein MA, Gardner R, et al. (2020) Increased proportion of physical child abuse injuries at a level I pediatric trauma center during the Covid-19 pandemic. Child Abuse Negl 104756. Link: https://bit.ly/3ayglqW

36. McKay T, Metzl J, Piemonte J (2020) Effects of Statewide Coronavirus Public Health Measures and State Gun Laws on American Gun Violence. Link: https://bit.ly/32BG9hh

37. Miller AR, Segal C Spencer MK (2020) Effects of the COVID-19 Pandemic on Domestic Violence in Los Angeles. National Bureau of Economic Research. Link: https://bit.ly/3newtmn

38. Babvey P, Capela F, Cappa C, Lipizzi C, Petrowski N, et al. (2020) Using social media data for assessing children's exposure to violence during the COVID-19 pandemic. Child Abuse Negl 104747. Link: https://bit.ly/3vaWiXn

39. WHO (2013) Global and regional estimates of violence against women prevalence and health effects of intimate partner violence and non-partner sexual violence. World Health Organization. Link: https://bit.ly/3gvHYEL

40. Parkinson D, Zara C (2013) The hidden disaster: domestic violence in the aftermath of natural disaster. Aust J Emerg Manag 28: 28-35. Link: https://bit.ly/3et85d0

\section{Discover a bigger Impact and Visibility of your article publication with} Peertechz Publications

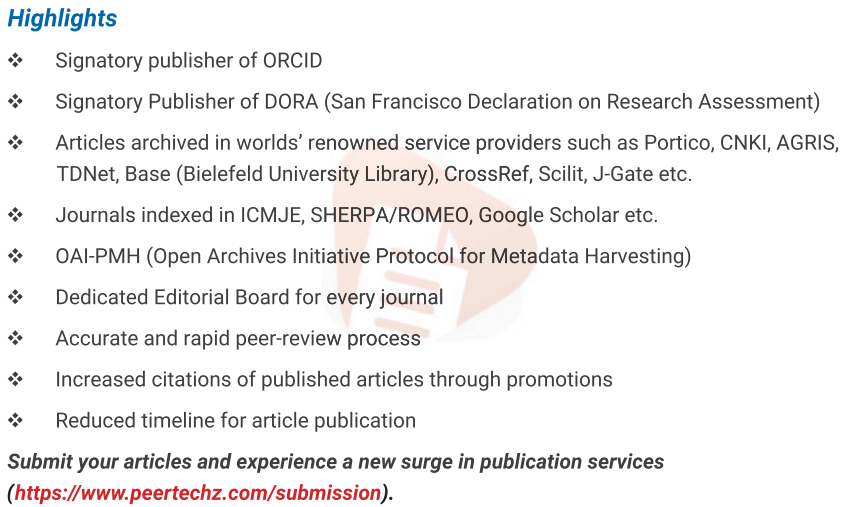

Copyright: (C) 2021 Figueiredo CP, et al. This is an open-access article distributed under the terms of the Creative Commons Attribution License, which permits unrestricted use, distribution, and reproduction in any medium, provided the original author and source are credited. 